\title{
Ring-opening Metathesis Polymerization derived hierarchically porous carbon-foams
}

\author{
Sebastijan Kovačič, ${ }^{a, *}$ Nadejda B. Matsko, ${ }^{b}$ Katharina Gruber, ${ }^{c}$ \\ Stefan Koller, ${ }^{c}$ Christian Slugovc ${ }^{d, *}$ \\ a National Institute of Chemistry, Department of Polymer Chemistry and Technology, \\ Hajdrihova 19, 1000 Ljubljana, Slovenia \\ ${ }^{\mathrm{b}}$ Graz Centre for Electron Microscopy (FELMI-ZFE), Steyrergasse 17, A 8010 Graz, Austria \\ ${ }^{c}$ Varta Micro Innovation GmbH, Stremayrgasse 9, A 8010 Graz, Austria \\ ${ }^{\mathrm{d}}$ Graz University of Technology, Institute of Chemistry and Technology of Materials, \\ Stremayrgasse 9, A8010 Graz, Austria; e-mail: slugovc@tugraz.at
}

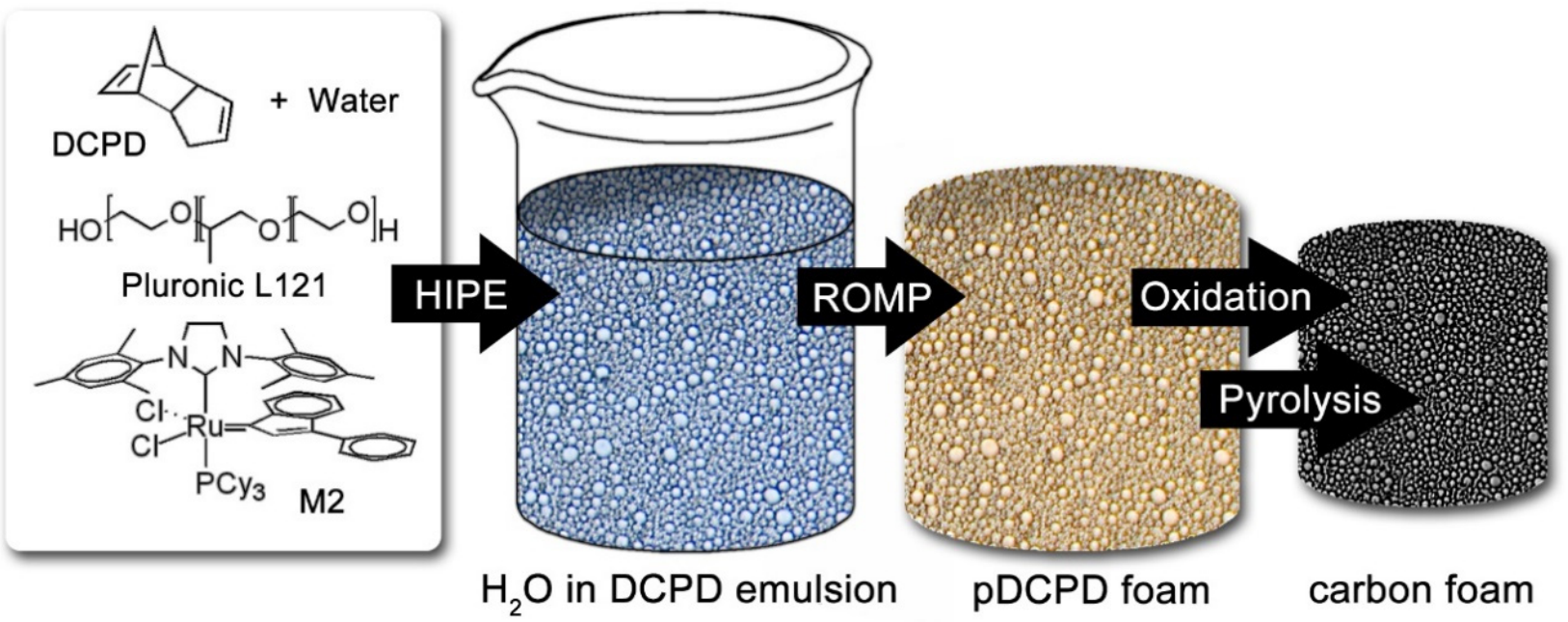

Monolithic open macroporous carbons of 80-85\% porosity are obtained from pyrolyzing oxidized high internal phase templated poly(dicyclopentadiene) foams. The macropores void diameters of the resulting carbon foams can be adjusted between 87 and $2.5 \mu \mathrm{m}$ simply by changing the surfactant amount used in the preparation of the precursor foams. The resulting porous carbon materials are characterized by a carbon content $>97 \%$, an electronic conductivity of up to 2800 $\mathrm{S} \cdot \mathrm{m}^{-1}$, a Young's modulus of up to $2.1 \mathrm{GPa}$ and a specific surface area of up to $1200 \mathrm{~m}^{2} \cdot \mathrm{g}^{-1}$. All these properties are largely owing to the pyrolysis conditions.

Introduction. Ring-Opening Metathesis Polymerization (ROMP) has become one of the most versatile polymerization techniques finding application in many areas of polymer and materials research. ${ }^{1}$ The ROMP of dicyclopentadiene (DCPD), which is a cheap by-product in the C5 stream of naphtha crackers, is of industrial relevance for the fabrication of e.g. body panels for vehicles or cell covers for chloro-alkali plants, domestic waste water treatment units and large waste containers. ${ }^{2,3}$ The thermoset poly(dicyclopentadiene) (pDCPD) is characterized by excellent mechanical properties, i.e. high toughness and rigidity, and an outstanding chemical resistance. The latter property is ascribed to an autoxidation of 
the surface of pDCPD. ${ }^{4}$ Current research interest in pDCPD-based materials comprises polymerizable ferrofluids, ${ }^{5}$ membranes for purification purposes,${ }^{6}$ nanoporous $\mathrm{pDCPD},{ }^{7} \mathrm{pDCPD}$ aerogels, ${ }^{8}$ fibers made by electrospinning ${ }^{9}$ and macroporous foams. ${ }^{10}$ Macroporous foams are, in the context of this work, of particular interest. Generally, cellular polymer foams are usually prepared by chemical or physical foaming whereby the cell sizes, morphologies as well as the preparation of fully open-cell structures are difficult to control. ${ }^{11}$ An alternative, offering a solution for that obstacle, is provided by the so called emulsiontemplating approach. High Internal Phase Emulsions (HIPEs) are a special type of emulsions characterized by a droplet (internal) phase volume fraction exceeding $74.05 \%$ of the total emulsion volume. ${ }^{12}$ Their structure consist of deformed (polyhedral) and/or polydispersed droplets separated by a thin film of the continuous phase (made up by monomers). ${ }^{13}$ Polymerization of the continuous phase of a HIPE and removal of the droplets of the dispersed phase results in highly-macroporous and permeable matrices. The resulting foams are typically made up of highly 3D-interconnected macropores (so-called voids; of typical diameters between 5 and $20 \mu \mathrm{m}$ ) and interconnecting pores (so-called windows; typically between 0.1 and $2 \mu \mathrm{m}$ ). The materials are attractive for a wide range of applications including e.g. filter membranes, adsorbents, supports for solid phase chemistry, ion exchange resins, scaffolds for tissue engineering, hybrid materials and supports for $\mathrm{CO}_{2}$ capture. ${ }^{14}$ Another use is to carbonize the polymeric foams to obtain monolithically shaped macroporous carbon matrices. Already back in 1988 Edwards et al. published a way to produce macroporous carbons from emulsion templated foams. ${ }^{15}$ Key for their success was to produce a foam, which does not lose or change its macroporous morphology at the high temperature needed for the carbonization process. Nowadays several synthetic strategies for the preparation of macroporous carbon foams from poly(styrene) and poly(divinylbenzene), ${ }^{16}$ poly(acrylonitrile), ${ }^{17}$ furfural-phloroglucinol, ${ }^{18}$ tannin, ${ }^{19}$ Kraft black liquor, ${ }^{20} 2,5$-dihydroxy-1,4-benzoquinone and urea $^{21}$ or resorcinol-formaldehyde resin based ${ }^{22}$ templates are available. Emulsion templating is a more sustainable alternative to the so-called hard templating route for preparing similar carbon foam architectures. In the latter approach porosity is created upon removing inorganic templates (in most cases silica) after the pyrolysis step. ${ }^{23}$

Herein we wish to disclose a ROMP based approach using the commodity monomer DCPD towards the synthesis of macroporous microcellular carbon foams of tunable pore sizes, high electronic conductivity, and high specific surface area.

Results and Discussion. Following recently published protocols, ${ }^{10 \mathrm{c}}$ which allow to prepare pDCPD foams with varying cavity and window sizes just by varying the surfactant amount, HIPEs of water ( $80 \mathrm{vol} \%)$ in DCPD (20 v\%) were prepared. As the surfactant Pluronic-L121 was used (Fig. 1, left; amounts summarized in Table S1). Upon addition of the initiator $\mathbf{M} 2^{24}$ and heating of the emulsion for $2 \mathrm{~h}$ at $80^{\circ} \mathrm{C}$ monolithic macroporous foams characterized by different void and window sizes were obtained (Table 1). The foams were dried and exposed to air at $40^{\circ} \mathrm{C}$ for at least five days. During that time the specimens oxidized. ${ }^{10 a-c, 25}$ Full oxidation resulted in typical elemental analysis of $62-65 \% \mathrm{C}$ and $6-7 \% \mathrm{H}$ meaning that $28-32 \%$ oxygen was incorporated into the foams (Table S2). This oxidation step is crucial for maintaining the macroporous structure during pyrolysis (unoxidized samples carbonized upon loss of the porous structure; $c f$. Fig S1). The fixation step employed here is, compared to conventional protocols (e.g. sulfonation, ${ }^{26}$ hypercrosslinking, ${ }^{27}$ the use of Pickering-HIPE templating ${ }^{16 \mathrm{~b}}$ or oxidation in air at high temperature ${ }^{28}$ ) very mild and constitute a unique characteristic of the investigated system. 

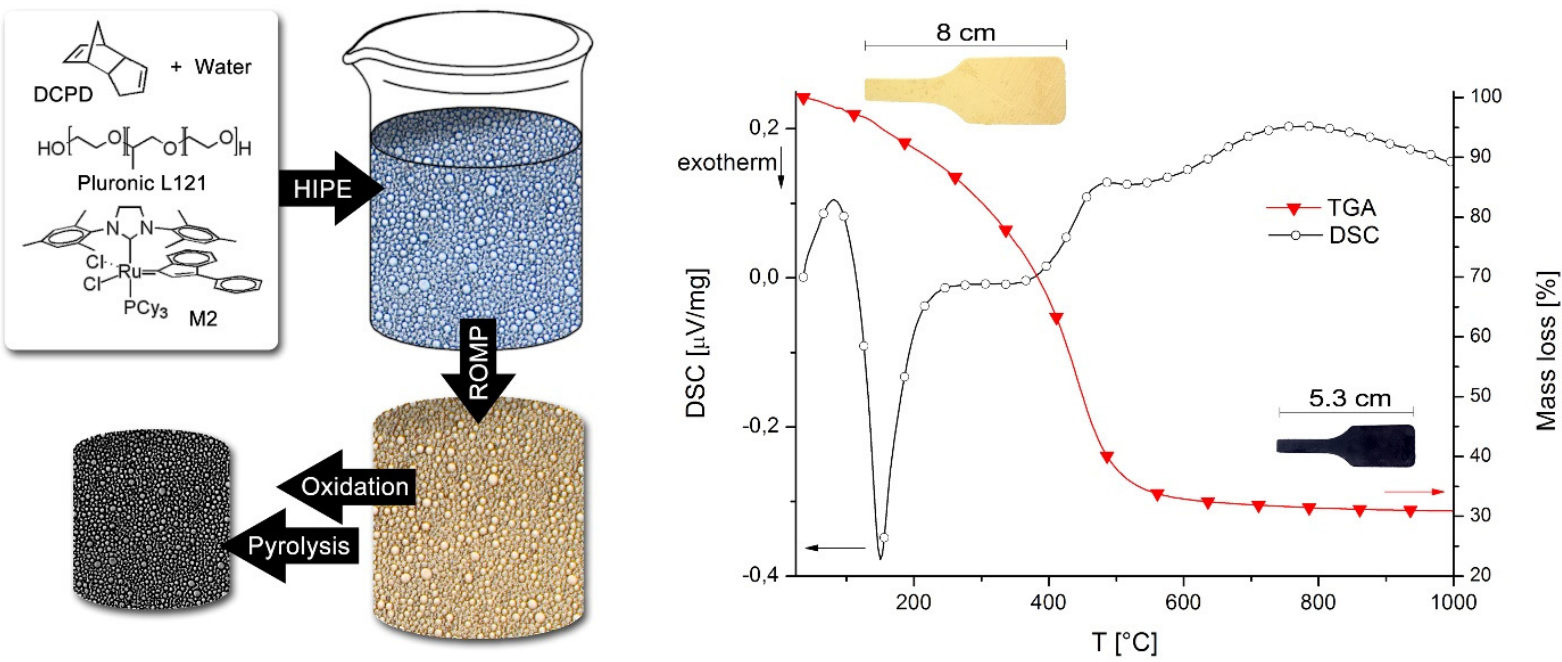

Fig. 1 left: preparation of the carbon foams; right: combined TGA/DSC investigation of the carbonization process; insets: photographs of a broken tensile test bar before (above) and after pyrolysis (below) indicating the sample's macroscopic shrinkage upon pyrolysis.

Then, pyrolysis was carried out at $900^{\circ} \mathrm{C}$ under inert atmosphere of argon and resulted in $1.5 \pm 0.1$ fold shrinkage of the macroscopic dimensions of the specimen accompanied with a mass loss of $70 \pm 3 \%$ as revealed from thermogravimetric investigations (Fig. 1, right and Fig S2). The foams' morphologies were evaluated using scanning electron microscopy (SEM). The characteristic HIPE derived foam morphology was preserved in the carbonized specimens. Macroporous carbon foams with cavities diameters from $2.5 \pm 0.9$ (HIPE prepared with $10 \mathrm{v} \%$ of the surfactant) to $87 \pm 56 \mu \mathrm{m}(0.25 \mathrm{v} \%$ surfactant used) were obtained (Table 1 and Fig. 2 and Figs. S3).

Table 1 Porosity and cavity sizes of foams prepared with different surfactant amounts before and after carbonization for $2 \mathrm{~h}$ at $900^{\circ} \mathrm{C}$

\begin{tabular}{|c|c|c|c|c|}
\hline Sample $^{a}$ & $\begin{array}{c}\text { Porosity before } \\
\text { carbonization [\%] }^{\mathrm{b}}\end{array}$ & $\begin{array}{c}\text { Void sizes before } \\
\text { carbonization }[\mu \mathrm{m}]^{\mathrm{c}}\end{array}$ & $\begin{array}{c}\text { Porosity after } \\
\text { carbonization [\%] }^{\mathrm{d}}\end{array}$ & $\begin{array}{c}\text { Void sizes after } \\
\text { carbonization }[\mu \mathrm{m}]^{\mathrm{e}}\end{array}$ \\
\hline $\mathrm{pDCPD}_{0.25}$ & 80 & $69 \pm 53$ & 82 & $87 \pm 56$ \\
\hline $\mathrm{pDCPD}_{1}$ & 81 & $35 \pm 23$ & 82 & $33 \pm 10$ \\
\hline $\mathrm{pDCPD}_{3}$ & 80 & $7.4 \pm 5.5$ & 84 & $10 \pm 6$ \\
\hline $\mathrm{pDCPD}_{5}$ & 81 & $6.7 \pm 2.6$ & 85 & $6.4 \pm 2.5$ \\
\hline $\mathrm{pDCPD}_{7}$ & 82 & $4.2 \pm 2.4$ & 85 & $4.3 \pm 1.6$ \\
\hline $\mathrm{pDCPD}_{10}$ & 79 & $3.4 \pm 1.2$ & 84 & $2.5 \pm 0.9$ \\
\hline
\end{tabular}

a foams prepared with different surfactant loading given in the subscript in vol\% in respect to DCPD; ${ }^{b}$ experimental porosity assessed from mercury porosimetry, see Ref. $10 \mathrm{c}$; ${ }^{\mathrm{c}}$ diameter; determined by SEM of broken samples, see Ref. $10 \mathrm{c} ;{ }^{d}$ experimental porosity assessed from mercury porosimetry of samples carbonized at $900^{\circ} \mathrm{C}$ (heating ramp 4 ${ }^{\circ} \mathrm{C} \cdot \mathrm{min}^{-1}, 2 \mathrm{~h}$ at $\left.900^{\circ} \mathrm{C}\right) ;{ }^{e}$ diameter, determined by SEM of broken samples

These values are similar to the void diameter of the oxidized specimen before pyrolysis (Table 1$)^{10 \mathrm{c}}$ Taking into account that the specimens shrinked by the factor of 1.5 upon carbonization, the by and large unchanged void sizes are at first sight surprising. However, this phenomenon has been already described for other systems and seems to be a not unusual feature in carbonizing macroporous foams. ${ }^{14 b, 16 \mathrm{~d}, 20}$ The herein disclosed systems thus allows for determining the cavity sizes of the carbon foam by variation of the surfactant amount used during the synthesis of the precursor foams. 


\section{Chem Rxiv}

The carbon foams exhibited, according to elemental analysis, a high carbon content of $96-98 \%$. Other elements present were hydrogen $(<1 \%)$ and oxygen $(1.4-3.3 \%)$ (Table S2).

In the next step, the influence of the carbonization temperature on the physical properties of carbon foams was investigated by pyrolysing oxidized pDCPD foams prepared with $7 \mathrm{v} \%$ surfactant at $500^{\circ} \mathrm{C}, 700^{\circ}$, $900^{\circ}, 1100^{\circ} \mathrm{C}$ and $1400^{\circ} \mathrm{C}$ for $2 \mathrm{~h}$ in argon atmosphere. Irrespective of the pyrolysis temperature, the morphology of the carbon foams was greatly preserved after pyrolysis and void sizes between $3.9 \pm 1.5 \mu \mathrm{m}$ and 4.6 \pm 1.6 in diameter as well as window sizes between $1.2 \pm 0.6 \mu \mathrm{m}$ and $2.7 \pm 0.9 \mu \mathrm{m}$ in diameter (Table 2, Figs. S3) were obtained as revealed by SEM analysis.
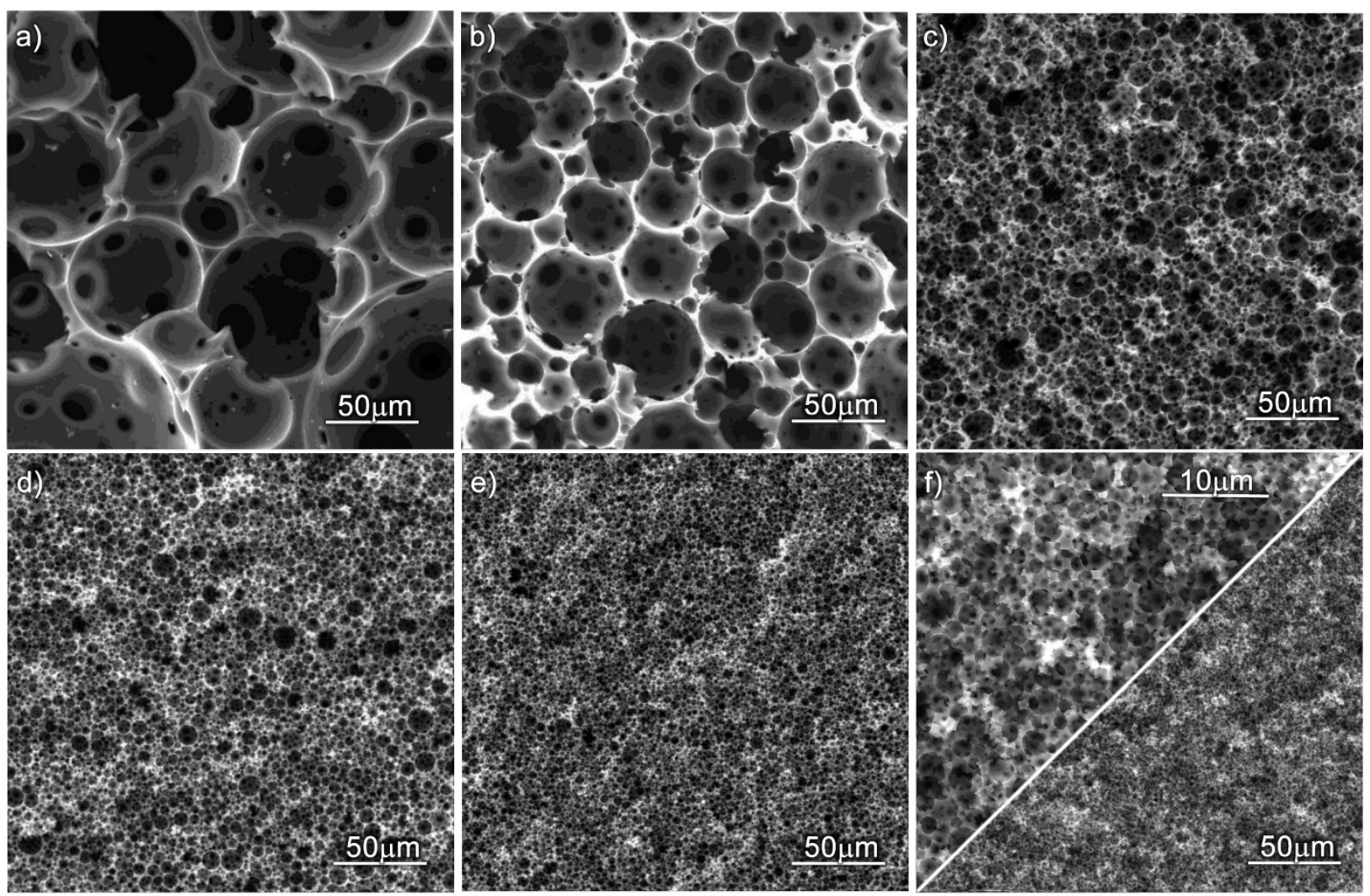

Fig. 2 Morphology of the carbon foams obtained from pyrolyzing pDCPD foams of 80\% nominal porosity prepared with a) $0.25 \mathrm{vol} \%$, b) 1 vol $\%$, c) 3 vol $\%$, d) 5 vol $\%$, e) 7 vol $\%$ and f) 10 vol $\%$ surfactant (above shown in a higher magnification)

The carbon foams exhibited porosity in the range of $79-85 \%$ as indicated from mercury porosimetry data and a specific surface area from $2.5-22.6 \mathrm{~m}^{2} \cdot \mathrm{g}^{-1}$ was determined using $\mathrm{N}_{2}$ desorption measurements (BET method). The somewhat increased surface area of samples pyrolyzed at $900^{\circ} \mathrm{C}$ can be attributed to the formation of small macropores (with diameters of approx. $350 \mathrm{~nm}$ ) within the polymer matrix as apparent from atomic force microscopy (AFM) investigations (Fig. 3, left, Fig. S4 and TEM Fig S5). This pore formation is explained by gas evolvement during the carbonization process. ${ }^{29}$ The skeletal densities of the carbon foams were determined by helium pycnometry and increased from $1.380 \mathrm{~g} \cdot \mathrm{cm}^{-3}$ at $500^{\circ} \mathrm{C}$ to 2.090 $\mathrm{g} \cdot \mathrm{cm}^{-3}$ at $900^{\circ} \mathrm{C}$. At higher pyrolysis temperatures the skeletal density was again decreasing reaching 1.680 $\mathrm{g} \cdot \mathrm{cm}^{-3}$ at $1400^{\circ} \mathrm{C}$ (Table 2). All skeletal densities observed here are lower than the density of graphite (2.25

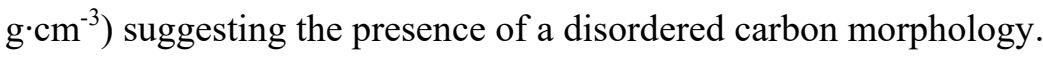


Table 2 Physical properties of carbon foams prepared from $\mathrm{pDCPD}_{7}$ at different temperatures

\begin{tabular}{|c|c|c|c|c|c|c|c|}
\hline $\begin{array}{l}\text { Temp. } \\
{\left[{ }^{\circ} \mathrm{C}\right]^{\mathrm{a}}}\end{array}$ & $\begin{array}{c}\text { Porosity } \\
\text { [\%] }^{c}\end{array}$ & $\begin{array}{c}\text { Void sizes } \\
{[\mu \mathrm{m}]^{d}}\end{array}$ & $\begin{array}{c}\text { Window sizes } \\
{[\mu \mathrm{m}]^{\mathrm{d}}}\end{array}$ & $\begin{array}{l}\text { He dens. } \\
{\left[\mathrm{g} \cdot \mathrm{cm}^{-3}\right]^{\mathrm{e}}}\end{array}$ & $\begin{array}{c}\text { BET } \\
{\left[\mathrm{m}^{2} \cdot \mathrm{g}^{-1}\right]^{f}}\end{array}$ & $\begin{array}{c}\text { BET } \\
{\left[\mathrm{m}^{2} \cdot \mathrm{g}^{-1}\right]^{\mathrm{g}}}\end{array}$ & $\begin{array}{l}\text { Elec. Cond. } \\
{\left[\mathrm{S} \cdot \mathrm{m}^{-1}\right]^{\mathrm{h}}}\end{array}$ \\
\hline 500 & 79 & $4.2 \pm 1.2$ & $1.5 \pm 0.9$ & 1.38 & 2.50 & $497 \pm 3$ & I \\
\hline 700 & 81 & $4.6 \pm 1.6$ & $2.1 \pm 0.9$ & 1.69 & 3.10 & $1182 \pm 9$ & 61 \\
\hline 900 & 85 & $4.3 \pm 1.6$ & $1.2 \pm 0.6$ & 2.09 & 22.6 & $626 \pm 4$ & 1150 \\
\hline 1100 & 85 & $4.5 \pm 1.5$ & $2.0 \pm 1.6$ & 2.07 & 10.1 & $946 \pm 6$ & 2410 \\
\hline 1400 & 81 & $3.9 \pm 1.5$ & $2.7 \pm 0.9$ & 1.68 & 4.10 & $313 \pm 1$ & 2790 \\
\hline $1400^{b}$ & 79 & $4.2 \pm 1.4$ & $1.2 \pm 0.6$ & 1.68 & 14.2 & n.d. & 2590 \\
\hline
\end{tabular}

a carbonization temperature, heating ramp $4{ }^{\circ} \mathrm{C} \cdot \mathrm{min}^{-1}, 2 \mathrm{~h}$ at given temperature; b heating ramp $4{ }^{\circ} \mathrm{C} \cdot \mathrm{min}^{-1}, 8 \mathrm{~h}$ at given temperature; ${ }^{c}$ experimental porosity assessed from mercury porosimetry data; ${ }^{d}$ diameter; determined by SEM of broken samples; ${ }^{\text {e }}$ skeletal density determined by helium pycnometry; ${ }^{f}$ surface area determined by $\mathrm{N}_{2}$-adsorption measurements (BET-method); ${ }^{9}$ surface area after activation with $\mathrm{CO}_{2}$ at the temperature listed in the first column as determined by $\mathrm{N}_{2}$-adsorption measurements (BET-method); ${ }^{\mathrm{h}}$ electric conductivity determined by a four point method

Further information on the carbon morphology in the nanoscale was retrieved from high resolution TEM micrographs (Fig. 3 right) showing increasing ordering of the carbon with increasing temperature of carbonization.
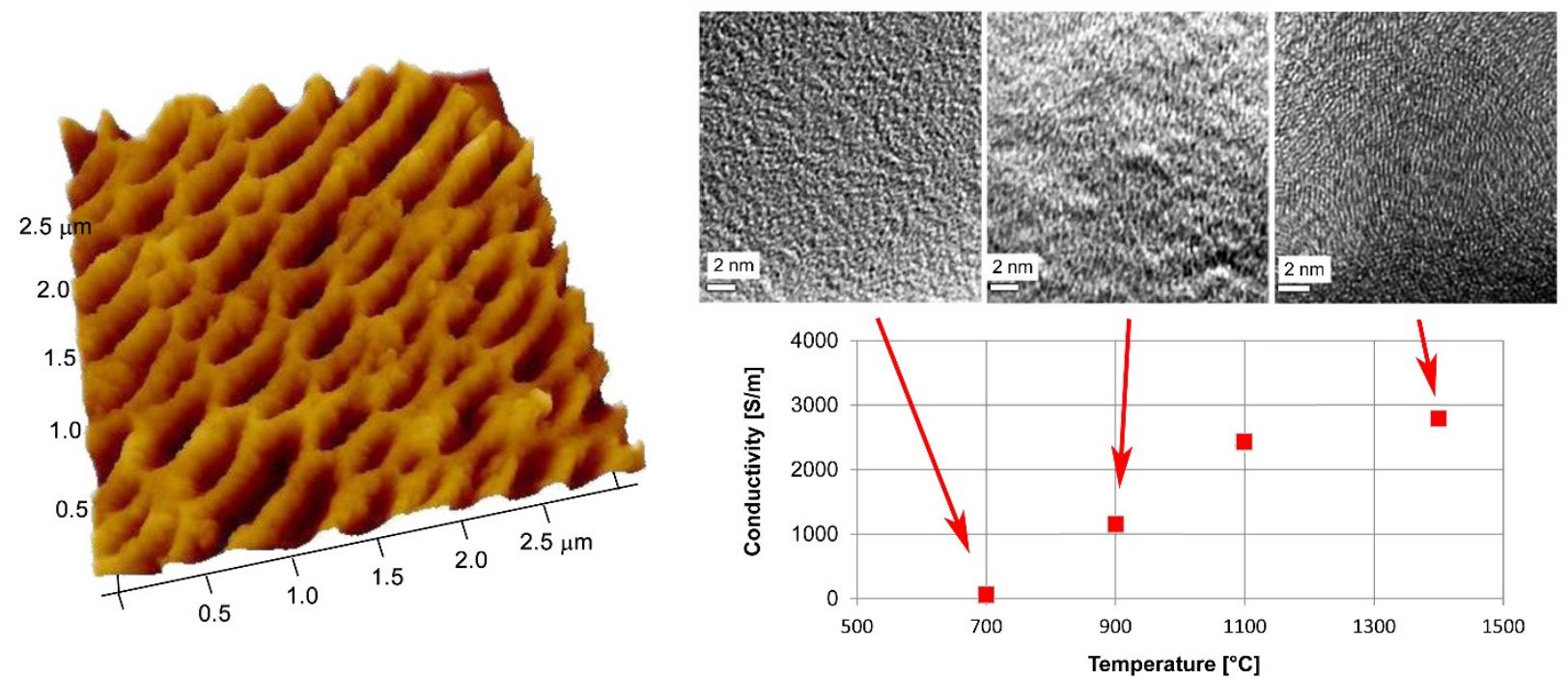

Fig.3 left: AFM picture of a carbonized foam-wall; right: HR-TEM pictures of the carbon morphology obtained by pyrolyzing at $700^{\circ} \mathrm{C}$ (left), $900^{\circ} \mathrm{C}$ (middle) and $1400^{\circ} \mathrm{C}$ (right) and conductivity vs. temperature of pyrolysis plot

Electron energy loss spectroscopy (EELS) in the TEM mode confirmed this impression showing the appearance of a feature at $6.5 \mathrm{eV}$ energy loss corresponding to an orientation-dependent EELS excitation process of the $\pi-\pi^{*}$ transition in samples treated at higher temperatures. Low-loss spectra of the sample treated at $500^{\circ} \mathrm{C}$ clearly indicate the presence of a fully amorphous carbon modification. ${ }^{30}$ Similarly, the $\pi^{*}$ peak at the C-K-edge (at $284 \mathrm{eV}$ energy loss) is increasing and it can be concluded that the degree of graphitization is increasing with increasing temperature of pyrolysis (Fig. S6). ${ }^{31}$ This trend can be macroscopically confirmed by the increase of the specimens' electronic conductivity with increasing pyrolysis temperature. ${ }^{32}$ Carbon foams treated at $500^{\circ} \mathrm{C}$ are poor conductors while a maximum conductivity of about $2800 \mathrm{~S} \cdot \mathrm{m}^{-1}$ was measured for the sample pyrolyzed at $1400^{\circ} \mathrm{C}$ for $2 \mathrm{~h}$ (Fig. 3, right; Tables 2 and S4). Finally, the mechanical properties of specimen prepared at $500^{\circ} \mathrm{C}$ and $900^{\circ} \mathrm{C}$ were determined by tensile testing. The Young's moduli increased from $1.1 \pm 0.2 \mathrm{GPa}$ (pyrolysis at $500^{\circ} \mathrm{C}$ ) to $2.1 \pm 0.3 \mathrm{GPa}$ 
$\left(900^{\circ} \mathrm{C}\right)$. Fracture is not occurring before $2.8 \pm 0.2 \mathrm{MPa}\left(500^{\circ} \mathrm{C}\right)$ or $13.4 \pm 0.6 \mathrm{MPa}\left(900^{\circ} \mathrm{C}\right)$ stress is applied resulting in $0.3 \pm 0.05 \%$ and $1.3 \pm 0.3 \%$ elongation respectively. Specimen prepared at $1400^{\circ} \mathrm{C}$ were too brittle to be measured (Fig. S7, Table S5).

As mentioned, the specific surface area of the macroporous carbon foams is rather low. Post-synthetic surface activation by carbon dioxide is known to provide a remedy and high specific surface areas by creating micro- and mesoporosity can be achieved with this treatment. ${ }^{33}$ Accordingly, the carbon foams were exposed to $\mathrm{CO}_{2}$ (flow rate $10 \mathrm{~cm}^{3} \cdot \mathrm{min}^{-1}$ ) at elevated temperatures. This treatment led to a significant increase of the surface areas (Table 2) depending on the temperature at which the activation was carried out. $\mathrm{N}_{2}$ physisorption isotherms after the treatment showed noticeable $\mathrm{N}_{2}$ uptake at very low relative pressures, i.e. up to $0.1 \mathrm{p} / \mathrm{p}_{0}$ (Fig. 4 , left).
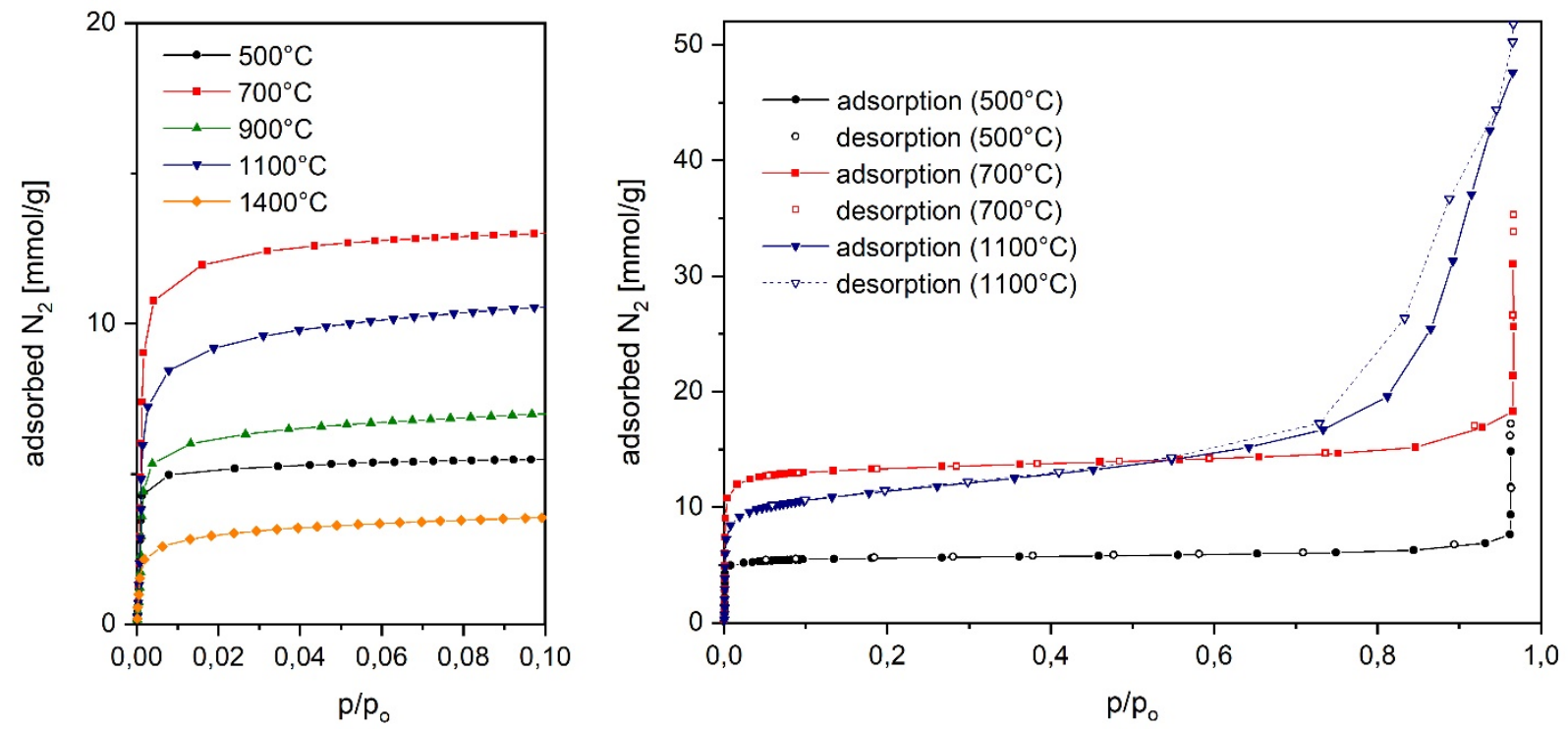

Fig. 4 left: $\mathrm{N}_{2}$ uptake at very low relative pressures; right: $\mathrm{N}_{2}$ isotherms measured at $77 \mathrm{~K}$ of carbon foams activated at $500^{\circ} \mathrm{C}, 700^{\circ} \mathrm{C}$, and $1100^{\circ} \mathrm{C}$. Adsorption is represented by full symbols, desorption by empty symbols.

This clearly indicates the presence of micropores exhibiting a uniform pore size distribution in all cases. The specific surface areas were calculated using the B.E.T. method $\left(\mathrm{S}_{\mathrm{BET}}\right)$ and revealed the highest $\mathrm{S}_{\mathrm{BET}}$ value of $1182 \mathrm{~m}^{2} \cdot \mathrm{g}^{-1}$ for the foam activated at $700^{\circ} \mathrm{C}$. The lowest surface area $\left(313 \mathrm{~m}^{2} \cdot \mathrm{g}^{-1}\right)$ was found for the foam activated at $1400^{\circ} \mathrm{C}$. Samples activated at lower temperatures (i.e. $500{ }^{\circ} \mathrm{C}$ and $700{ }^{\circ} \mathrm{C}$ ) exhibited typical Type I isotherm with only one additional steep increase at the relative pressures close to 1, which can be assigned to the presence of macropores (Fig. 4, right). The isotherms of samples activated at temperatures higher than $900^{\circ} \mathrm{C}$ can be assigned to the Type II isotherm exhibiting a hysteresis loop, indicating the presence of mesopores with broad opening size distribution (Fig. 4, right and Fig. S8). The presence of the mesoporosity was further rationalized by HR-TEM analysis and mesopores of $10-30 \mathrm{~nm}$ in diameter were observed (Figs. S9 and S10). Moreover, the presence of very uniform curved nano channels (approx. $0.35 \mathrm{~nm}$ ) were found upon activation (Fig. S10) that were not accessible before (upper right images in Fig. 3). ${ }^{34}$

Results described so far were typically obtained from monolithic cylindrical carbon specimen (diameter: $1.3 \mathrm{~cm}$; height: $2.7 \mathrm{~cm}$ ) or cuboidal specimen (for the four point conductivity measurements; length $=20$ 
$\mathrm{cm}$; width $=1.5 \mathrm{~cm}$; height $=0.5 \mathrm{~cm}$ ). Moreover, it is worth noting that other macroscopic shapes of the carbon foams are easily accessible. To demonstrate this, a pDCPD foam membrane of approx. $130 \mu \mathrm{m}$ thickness was prepared according to Ref. $10 \mathrm{~g}$, oxidized and subsequently carbonized at $700^{\circ} \mathrm{C}$ for $2 \mathrm{~h}$. The resulting macroporous carbon foam membrane was obtained in one piece featuring a size of $5 \times 5 \mathrm{~cm}$ and a thickness of about $80 \mu \mathrm{m}$ (Fig. S11).

Conclusion. In summary, it has been demonstrated that emulsion templated p(DCPD) cured via Ringopening Metathesis Polymerization can be carbonized yielding macroporous carbon foams. Prerequisite for the conservation of the macroporous structure is an oxidation of the pristine $\mathrm{p}(\mathrm{DCPD})$ foams. This oxidation step is accomplished under mild conditions using only air. The carbonization yields macroporous carbon foams of high carbon purity ( $>97 \%$ ), a porosity of $80-85 \%$ and low surface areas of up to $20 \mathrm{~m}^{2} \cdot \mathrm{g}^{-1}$. Depending on the carbonization temperature the mechanical properties and the conductivity of the monolithic carbon foams can be adjusted. The highest conductivity of approx. $2800 \mathrm{~S} \cdot \mathrm{m}^{-1}$ was achieved by conducting the pyrolysis at $1400^{\circ} \mathrm{C}$. The highest Young's modulus of $2.1 \mathrm{GPa}$ was obtained by carbonizing at $1100^{\circ} \mathrm{C}$. Furthermore, the void sizes of the macroporous carbon foams can be easily tuned in the range between 87 and $2.5 \mu \mathrm{m}$ by variation of the surfactant amount used for preparing the precursor foams. Upon activation by a $\mathrm{CO}_{2}$ treatment the surface area can be boosted to up to $1200 \mathrm{~m}^{2} \cdot \mathrm{g}^{-1}$. Using different temperatures in this activation step allow for the preparation of macroporous foams featuring additional microporosity or combined micro- and mesoporosity. The herein disclosed carbonization method for macroporous pDCPD foams should also allow for converting other pDCPD based materials such as electrospinned fibers or pDCPD aerogels into porous carbons.

\section{Experimental}

Materials. Dicyclopentadiene (DCPD, Aldrich), Pluronic L-121 (poly(ethylene glycol)-block-poly(propylene glycol)-block-poly(ethylene glycol, Aldrich), the initiator $\left(\mathrm{H}_{2} \mathrm{IMes}\right)\left(\mathrm{PCy}_{3}\right) \mathrm{Cl}_{2} \mathrm{Ru}$ (3-phenyl-indenylid-1-ene) (M2, Umicore, $\mathrm{H}_{2} \mathrm{IMes}=\mathrm{N}, \mathrm{N}$-bis(mesityl) 4,5-dihydroimidazol-2-yl), $\mathrm{PCy}_{3}=$ tricyclohexylphosphine)) and toluene (p.a. Aldrich) were used as received.

Synthetic procedure. The according amounts of monomer DCPD, Pluronic L121, (Table S1), and toluene (50 $\mu \mathrm{L}$ ) were placed in a 3 neck round-bottomed flask equipped with a mechanical stirrer and a dropping funnel. The mixture was stirred at $400 \mathrm{rpm}$ for $5 \mathrm{~min}$ and upon continuous stirring deionized water was added drop-wise at $25^{\circ} \mathrm{C}$ over about $1 \mathrm{~h}$. Afterwards, the initiator $\mathbf{M 2}(1.3 \mathrm{mg}, 0.0007 \mathrm{mmol}$ in respect to DCPD) dissolved in toluene $(0.25 \mathrm{~mL})$ was added and the emulsion was stirred for further $5 \mathrm{~min}$. Subsequently, the emulsion was transferred to appropriate mold (i.e. glass vials) and the filled molds were transferred into a preheated oven operating under air. Curing of the emulsions at $80^{\circ} \mathrm{C}$ for $4 \mathrm{~h}$ resulted in the formation of white rigid monoliths in all cases. The specimens were purified by Soxhlet extraction with acetone for $24 \mathrm{~h}$ and subsequently dried in a desiccator under vacuum (10 mbar) until constant weight was reached. Such obtained specimens were placed in an oven operated in air and stored there for at least $5 \mathrm{~d}$. Yet oxidized specimens were placed on a quartz boat in a quartz tube in the isothermal zone of a tubular furnace operated under argon. The samples were then heated to the temperature as listed in Table 1 or with the heating ramp of $4 \mathrm{~K} / \mathrm{min}$.

Carbon dioxide activation. The carbon dioxide activations were performed using $500 \mathrm{mg}$ of carbon foam for each batch. The raw material was placed in a quartz boat in a quartz tube in the isothermal zone of a tubular furnace and purged with flowing argon. The samples were then heated to the temperature as listed in Table 1 (temperatures given are of the furnace) with the heating ramp of $4 \mathrm{~K} / \mathrm{min}$ followed by subsequently changing the gas flux to carbon dioxide with the flow of $10 \mathrm{~mL} / \mathrm{min}$ and annealed. Samples were cooled to room temperature under flowing argon.

Characterization. TGA measurements were performed with a Netzsch Simultaneous Thermal Analyzer STA 449 F1 Jupiter (crucibles: aluminium from Netzsch). A nitrogen flow of $50 \mathrm{~mL} \mathrm{~min}{ }^{-1}$ was used in combination with a protective flow of helium of $8 \mathrm{~mL} \mathrm{~min}{ }^{-1}$. The heating rate until a final temperature of $1100^{\circ} \mathrm{C}$ was $10^{\circ} \mathrm{C} \mathrm{min}^{-1}$. Morphology investigations were performed using scanning electron microscopy. SEM images were taken on a Field emission electron microscope Ultra+ (Carl Zeiss) equipped with energy dispersive spectrometer SDD X-Max 50 (Oxford Instruments). Piece of the each sample was mounted on a carbon tab for better conductivity and thin layer of 
gold was sputtered on samples surface prior to scanning analysis. For TEM analysis, samples were embedded in Araldite/Epon embedding mixture, which was composed of $49 \%$ w/w Araldite/Epon stock solution, $49 \%$ w/w hardener DDSA (Fluka) and $2 \% \mathrm{w} / \mathrm{w}$ accelerator DMP-30 (Fluka). Infiltration was performed stepwise (impregnation at room temperature for $24 \mathrm{~h}$, and polymerization at $50^{\circ} \mathrm{C}$ for $72 \mathrm{~h}$ ). Embedded samples were sectioned using Leica Ultracut ultramicrotome to a thickness between 70 and $120 \mathrm{~nm}$. All EFTEM experiments were acquired in TEM mode. For the calculation of elemental distribution images, a jump ratio method was used. The high resolution transmission electron microscopy were done on a 200-kV field-emission gun microscope JEOL JEM 2100. Samples were dispersed in ethanol and placed on a copper holey carbon grid. Nitrogen adsorption measurements of carbon foams were performed on IMI-HTP manometric gas analyzer (Hiden Isocehma). After degassing of the samples at $100{ }^{\circ} \mathrm{C}$ for 2 hours in dynamic vacuum, the skeletal sample density was measured using helium pycnometry (99.999\% He; Messer) at $25{ }^{\circ} \mathrm{C}$ for the dead volume corrections. The specific surface areas were determined by the Brunauer-Emmett-Teller (BET) method in accordance with ISO 9277:2010(E) standards.

Acknowledgements. Support by Graz University of Technology (LP-03 - Porous Materials@Work) and from Varta Micro Innovation $\mathrm{GmbH}$ is kindly acknowledged. We thank Umicore for providing initiators and Matjaž Mazaj (National Institute of Chemistry, Ljubljana) as well as Karel Jerabek (Czech Academy of Science) for measurements.

Supporting Information: Details on preparation, elemental analyses, SEM, AFM, TEM and HR-TEM pictures, electron energy loss spectra, conductivity measurement, tensile testing and adsorption measurements.

\section{References}

1 a) C. W. Bielawski and R. H. Grubbs, Prog. Polym. Sci., 2007, 32, 1; b) A. Leitgeb, J. Wappel and C. Slugovc, Polymer, 2010, 51, 2927; c) J. P. Moerdyk and C. W. Bielawski, Polymer Science: A Comprehensive Reference, Vol. 4, p523-550, Elsevier: Amsterdam, 2012; d) C. Slugovc, Handbook of Metathesis $2^{\text {nd }}$ Edition (R. H. Grubbs, E. Kosravi, Eds.), Vol. 3, p1-16, Wiley-VCH: Weinheim, 2015.

2 a) J. C. Mol, J. Mol. Catal. Part A: Chem., 2004, 213, 39; b) M. S. Trimmer, Handbook of Metathesis, Vol. 3, p407-414, Wiley-VCH: Weinheim, 2003; c) A. Nickel, B. D. Edgecombe, Polymer Science: A Comprehensive Reference, Vol. 4, p749-759, Elsevier: Amsterdam, 2012.

3 P. Y. Le Gac, D. Choqueuse, M. Paris, G. Recher, C. Zimmer and D. Melot, Polym. Degrad. Stabil., 2013, 98, 809.

4 A. Mühlebach, P. A. van der Schaaf, A. Hafner and F. Setiabudi, J. Mol. Catal. A: Chem., 1998, 132, 181.

5 P. Bian and T. J. McCarthy, Langmuir, 2010, 26, 6145.

6 a) M. Perring and N. B. Bowden, Langmuir, 2008, 24, 10480; b) M. Perring, T. R. Long and N. B. Bowden, J. Mater. Chem., 2010, 20, 8679; c) T. R. Long, A. Gupta, A. L. Miller, D. G. Rethwisch and N. B. Bowden, J. Mater. Chem., 2011, 21, 14265; d) A. Gupta, T. R. Long, D. G. Rethwisch and N. B. Bowden, Chem. Commun., 2011, 47, 10236; e) A. Gupta and N. B. Bowden ACS Appl. Mater. Interfaces, 2013, 5, 924.

7 a) M. A. Amendt, L. Chen, M. A. Hillmyer, Macromolecules, 2010, 43, 3924; b) M. A. Amendt, M. Roerdink, S. Moench, W. A. Phillip, E. L. Cussler and M. A. Hillmyer, Aust. J. Chem., 2011, 64, 1074.

8 a) S. H. Kim, M. A. Worsley, C. A. Valdez, S. J. Shin, C. Dawedeit, T. Braun, T. F. Baumann, S. A. Letts, S. O. Kucheyev, K. J. J. Wu, J. Biener, Jr. J. H. Satcher, A. V. Hamza, RSC Adv., 2012, 2, 8672; b) D. P. Mohite, S. Mahadik-Khanolkar, H. Luo, H. Lu, C. Sotiriou-Leventis and N. Leventis, Soft Matter, 2013, 9, 1516; c) J. M. Lenhardt, S. H. Kim, A. J. Nelson, P. Singhal, T. F. Baumann and J. H. Satcher, Jr. Polymer, 2013, 54, 542.

9 L. M. Bellan, G. W. Coates and H. G. Craighead, Macromol. Rapid Commun. 2006, $27,511$.

10 a) S. Kovačič, P. Krajnc and C. Slugovc, Chem. Commun., 2010, 46, 7504; b) S. Kovačič, K. Jeřabek, P. Krajnc and C. Slugovc, Polym. Chem., 2012, 3, 325; c) S. Kovačič, N. B. Matsko, K. Jeřabek, P. Krajnc and C. Slugovc, J. Mater. Chem. A, 2013, 1, 487; d) S. Kovačič, H. Kren, P. Krajnc, S. Koller and C. Slugovc, Macromol. Rapid Commun., 2013, 34, 581; e) A.-C. Knall, S. Kovacic, M. Hollauf, D. P. Reishofer, R. Saf and C. Slugovc, Chem. Commun. 2013, 49, 7325; f) S. Kovačič, N. B. Matsko, G. Ferk and C. Slugovc, J. Mater. Chem. A. 2013, 1, 7971; g) S. Kovačič, F. Preishuber-Pflügl and C. Slugovc, Macromol. Mater. Eng. 2014, 299, 843; h) S. Kovačič, M. Mazaj, M. Jeselnik, D. Pahovnik, E. Žagar, C. 
Slugovc and N. Zabukovec Logar, Macromol. Rapid Commun. 2015, 36, 1605; i) S. Kovačič, F. Preishuber-Pflügl, D. Pahovnik, E. Žagar and C. Slugovc, Chem. Commun., 2015, 51, 7225-7228; j) N. Trupej, Z. Novak, Ž. Knez, C.Slugovc and S. Kovačič, J. CO2 Util., 2017, 21, 336; k) S. Kovačič, E. Žagar and C. Slugovc, Polymer, 2019, 169, 58; I) E. Vakalopoulou and C. Slugovc, Macromol. Chem. Phys., 2019, 220, 1900423.

11 S.-T. Lee and N. S. Ramesh, Polymeric Foams: Mechanisms and Materials $2^{\text {nd }}$ Ed., CRC Press: Boca Raton, 2009.

12 H. Zhanga and A. I. Cooper, Soft Matter, 2005, 1, 107; N. R. Cameron, Polymer, 2005, 46, 1439.

13 N. R. Cameron and D. C. Sherrington, Adv. Polym. Sci., 1996, 126, 163.

14 a) M. S. Silverstein, Prog. Polym. Sci., 2014, 39, 199; b) T. Zhang, R. A. Sanguramath, S. Israel and M. S. Silverstein, Macromolecules, 2019, 52, 5445.

15 C. J. C. Edwards, D. A. Hitchen and M. Sharples, US Patent, 4775655, 1988.

16 a) D. Wang, N. L. Smith and P. M. Budd, Polym. Int., 2005, 54, 297; b) R. T. Woodward, D. W. H. Fam, D. B. Antony, J. Hong, T. O. McDonald, C. Petit, M. S. P. Shaffer and A. Bismarck, Carbon, 2016, 101, 253; c) R. T. Woodward, A. Jobbe-Duval, S. Marchesini, D. B. Anthony, C. Petit and A. Bismarck, Polymer, 2017, 115, 146; d) F. Yi, Y. Gao, H. Li, L. Yi, D. Chen and S. Lu, Electrochim. Acta, 2016, 211, 768; e) W. Hu, F. Xie, Y. Li, Z. Wu, K. Tian, M. Wang, L. Pan and L. Li, Langmuir, 2017, 33, 13364; f) R. T. Woodward, F. De Luca, A. D. Roberts and A. Bismarck, Materials, 2016, 9, 776/1.

17 N. Cohen and M. S. Silverstein, Polymer, 2011, 52, 282.

18 N. Brun,; L. Edembe, S. Gounel, N. Mano and M. M. Titrici, ChemSusChem, 2013, 6, 701.

19 A. Szczurek, V. Fierro, A. Pizzi and A. Celzard, Carbon, 2014, 74, 352.

20 A. Foulet, M. Birot, R. Backov, G. Sonnemann and H. Deleuze, Mater. Today Commun., 2016, 7, 108.

21 K. Kapilov-Buchman, L. Portal, Y. Zhang, N. Fechler, M. Antonietti and M. S. Silverstein, J. Mater. Chem. A, 2017, 5, 16376.

22 A. F. Gross and A. P. Nowak, Langmuir, 2010, 26, 11378.

23 a) N. Brun, S. R. S. Prabaharan, M. Morcrette, C. Sanchez, G. Pecastaings, A. Derre, A. Soum, H. Deleuze, M. Birot and R. Backov, Adv. Funct. Mater., 2009, 19, 3136; b) J. Biener, M. Stadermann, M. Suss, M. A. Worsley, M. M. Viener, K. A. Rose and T. F. Baumann, Energy Environ. Sci., 2011, 4, 656.

24 A. Leitgeb, J. Wappel, C. A. Urbina-Blanco, S. Strasser, C. Wappl, C. S. J. Cazin and C. Slugovc, Monatsh. Chem., 2014, 145, 1513.

25 E. Vakalopoulou, S. Borisov and C. Slugovc, Macromol. Rapid Commun., 2020, DOI: 10.1002/marc.201900581

26 a) D. Wang, N. L. Smith and P. M. Budd, Polym. Internat., 2005, 54, 297; b) H. D. Asfaw, R. Younesi, M. Valvo, J. Maibach, J. Ångström, C.-W. Tai, Z. Bacsik, M. Sahlberg, L. Nyholm and P. K. Edström, ChemistrySelect, 2016, 1, 784.

27 S. Israel, I. Gurevitch and M. S. Silverstein, Polymer, 2015, 72, 453.

28 W. R. Even and D. P. Gregory, MRS Bulletin, 1994, 19, 29.

29 Z. Zhang, R. Brydson, Z. Aslam, S. Reddy, A. Brown, A. Westwood and B. Rand, Carbon, 2011, 49, 5049.

30 a) V. P. Oleshko, J. Nanosc. Nanotechnol. 2012, 12, 8580; M. Monthioux, F. Soutric and V. Serin, Carbon 1997, 35, 1660; H. R. Daniels, R. Brydson, A. Brown and B. Rand, Ultramicroscopy, 2003, 96, 547; b) V. P. Oleshko and J. M. Howe, J. Appl. Phys., 2007, 101, 054308-11.

31 Orientation-dependent EELS excitation processes such as the $\left(\pi-\pi^{*}\right)$ low-loss feature (at $6.5 \mathrm{eV}$ energy loss) and the $\pi^{*}$ peak at the C-K-edge (at $284 \mathrm{eV}$ energy loss) display an orientation dependence, which is too strong to use these peaks to quantify the degree of carbonization.

32 M. Sevilla and A. B. Fuertes, Carbon, 2013, 56, 155.

33 a) L. Borchardt, M. Oschatza and S. Kaskel, Mater. Horiz., 2014, 1, 157; b) C. Forgacz, M. Birot and H. Deleuze J. Appl. Polym. Sci., 2015, 132, 41215.

34 M. Oschatz, P. Pré, S. Dörfler, W. Nickel, P. Beaunier, J.-N. Rouzaud, C. Fischer, E. Brunner and S. Kaskel, Carbon, 2016, 105, 314. 